\title{
Örgütsel Çatışma ile Yabancılaşma Arasındaki İlişsi Üzerine Bir Araştırma
}

\author{
Yusuf Demirgül \\ Doktora Öğrencisi, Kırıkkale Üniversitesi, Sosyal Bilimler Enstitüsü, İșletme, Kırıkkale, Türkiye \\ yusufdemirgul@yahoo.com
}

\begin{tabular}{|c|c|}
\hline Makale Bilgileri & ÖZ \\
\hline Makale Geçmişi & $\begin{array}{l}\text { Örgütler, belirli bir amacı gerçekleştirmek üzere bir araya gelen bireylerden oluşan topluluklardır. } \\
\text { İnsan olgusunun bulunduğu bir ortamda çeşitli nedenlerden kaynaklanan çatışmaların doğması }\end{array}$ \\
\hline $\begin{array}{l}\text { Geliş: } 22.10 .2020 \\
\text { Kabul: } 23.11 .2020 \\
\text { Yayın: } 27.12 .2020\end{array}$ & $\begin{array}{l}\text { kaçınılmazdır. Ortaya çıkan bu çatışmanın örgütten tamamen temizlenmesi yerine belirli bir düzeyde } \\
\text { bulunması ve yönetilmesi günümüz işletme yönetimi anlayışına daha uygundur. Bu bağlamda } \\
\text { çatışma bulunan bir ortamda, çatışmayı yaşayan tarafların içinde bulundukları örgüte ve birlikte iş }\end{array}$ \\
\hline $\begin{array}{l}\text { Anahtar Kelimeler: } \\
\text { Örgüt, } \\
\text { Çatışma, } \\
\text { Yabancılaşma, } \\
\text { Yönetim }\end{array}$ & $\begin{array}{l}\text { gördükleri kişilere yabancılaşması ve aidiyet duygularını yitirme olasılı̆̆ göz ardı edilmemelidir. Bu } \\
\text { çalışma ile örgütlerde yaşanan çatışmanın yabancılaşmaya neden olup olmadığı deneysel bir } \\
\text { araştırma ile saptanmıştır. Söz konusu deneysel araştırma anket yöntemiyle bir bakanlığın merkez } \\
\text { teşkilatında bulunan ve gelişigüzel seçilen } 404 \text { çalışan üzerinde uygulanmıştır. Çalışanlara } \\
\text { demografik bilgileri, çatışma ve yabancılaşma algılarına ilişkin sorular yöneltilmiştir. Toplanan } \\
\text { veriler SPSS } 26 \text { programı kullanılarak analiz edilmiş ve bu süreçte çeşitli istatistiki metotlar } \\
\text { kullanılmıştır. Gerçekleştirilen bütün bu çalışmalar sonucunda örgütlerde meydana gelen çatışmanın, } \\
\text { çalışanlar üzerindeki yabancılaşmaya etkisi olduğu ortaya konulmuştur. Ayrıca cinsiyet ve medeni } \\
\text { durum gibi demografik değişkenlerin çatışma ve yabancılaşma üzerinde herhangi bir etkisinin } \\
\text { olmadığı sonucuna varılmıştır. }\end{array}$ \\
\hline
\end{tabular}

\section{A Research on the Relationship Between Organizational Conflict and Alienation}

\begin{tabular}{ll}
\hline Article Info & ABSTRACT \\
\hline Article History & $\begin{array}{l}\text { Organizations are communities of individuals who come together to achieve a specific goal. It is } \\
\text { inevitable that conflicts arising from various reasons will arise in an environment where there is a }\end{array}$ \\
$\begin{array}{l}\text { Received: } 22.10 .2020 \\
\text { Accepted: } 23.11 .2020\end{array}$ & $\begin{array}{l}\text { human phenomenon. It is more suitable for today's business management understanding to find and } \\
\text { mablished: } 27.12 .2020\end{array}$ \\
$\begin{array}{l}\text { context, in an environment of conflict, the possibility of alienation and losing sense of belonging to } \\
\text { the organization and the people they work with should not be overlooked. With this study, it is } \\
\text { determined by an empirical study whether the conflict in organizations caused alienation or not. This }\end{array}$ \\
$\begin{array}{l}\text { Keywords: } \\
\text { Organization, }\end{array}$ & $\begin{array}{l}\text { ministry and used a survey method. Employees were asked questions about their demographic } \\
\text { information, perceptions of conflict and alienation. The collected data were analyzed using the SPSS }\end{array}$ \\
Alienation, & $\begin{array}{l}\text { 26 program and various statistical methods were used in this process. As a result of all these studies } \\
\text { it has been revealed that the conflict that occurs in organizations has an effect on alienation on } \\
\text { Management }\end{array}$ \\
$\begin{array}{l}\text { employees. In addition, it was concluded that demographic variables such as gender and marital } \\
\text { status have no effect on conflict and alienation. }\end{array}$
\end{tabular}

Atıf/Citation: Demirgül, Y. (2020). Örgütsel Çatışma ile Yabancılaşma Arasındaki İlişki Üzerine Bir Araştırma, Necmettin Erbakan Üniversitesi Siyasal Bilgiler Fakültesi Dergisi, 2(2), 114-128 


\section{GİRIŞ}

Geçmişten günümüze kadar insanoğlunun bulunduğu hemen her ortamda bir takım nedenlerden dolayı çatışmalar yaşanmıştır ve yaşanmaya devam etmektedir. Tarihte çatışmaların birçoğu savaş gibi güç kullanımına yönelik eylemler ile sonlandırılmaya çalışılmıştır. Sanayi toplumuna geçiş ile birlikte büyük fabrikalarda çok uzun saatler birlikte çalışmaya başlayan insanlar, farklı nedenlerle işyerlerinde çatışmayı sürdürmüşlerdir. İşyerinde yaşanılan çatışmaların genellikle, çalışanlar arası, birimler arası ve çalışanlar ile amirleri arasında olduğu bilinmekle birlikte, işverenler açısından bu tür çatışmaların, işyerleri açısından tehlike oluşturduğu ve sonlandırılması gerektiği düşünülse de, günümüzde belirli bir düzeyde var olan çatışmanın yönetilmesi daha akılcı bir yönetim anlayışını tarafımıza sunmaktadır. $\mathrm{Bu}$ bağlamda, örgütlerde çatışmanın yönetilmesi bakımından yapılan çalışmalar, çatışmanın nedenlerini, çatışmayı etkileyen faktörleri ve sonuçlarını ortaya koyma zorunluluğunu açığa çıkarmıştır.

Örgüt, insanların bir araya gelmesi sonucu ortaya çıkan bir kavram olduğundan, insanları bireysel ya da toplu olarak etkileyen fiziksel ve psikolojik olguların irdelenmemesi ve konuyla ilişkilendirilmemesi düşünülemez. İnsanların bir takım nedenlerle üyesi oldukları örgüte aidiyet hissini azaltan ve yalnızlaştıran nedenler bulunmaktadır. Bu nedenlerin araştırılıp, çözüme kavuşturulamaması, örgütlerin belirledikleri hedef ve amaçlarına ulaşamamalarına ya da daha geç ve daha yüksek maliyetli bir şekilde ulaşmalarına yol açar.

$\mathrm{Bu}$ bağlamda, örgütlerde var olan çatışmanın, çalışanların yabancılaşmasına etkisinin olup olmadığ1, etkisi var ise hangi oranda bir etkide bulunduğu ile bir takım değişkenlerin bu etkileme düzeyini nasıl değiştirdiğine ilişkin problemler bu çalışma ile incelenmiştir.

\section{LITERATÜR}

\section{Çatışma}

Çatışma kavramı insanoğlunun var olduğu günden bugüne kadar çeşitli formlarda karşısına çıkmıştır. Tarihte daha çok savaşmak anlamında kullanılan çatışma, günümüzde sosyoloji ve psikoloji bilimlerinin de dahil olduğu daha geniş bir anlamı ifade etmektedir. Çok değişik sahalarda karşılaşılan çatışmanın kesin ve standart bir tanımını ortaya koymak zordur (Korkmaz,1994:77). Kelime anlamı olarak, çatışmak işi olarak tanımlanan (Genel Türkçe Sözlük,2017) çatışma kavramı genel olarak, görüşlerin farklılığından ortaya çıkan karşıtlık olarak açılanmıştır (Yöntembilim Terimleri Sözlügü̈,1981). Sonuç olarak çatışma, iki veya daha fazla şahıs ya da grubun; amaçlar, talepler, beklentiler, hedefler ya da güdülerinin birbiriyle uyumlu olmaması durumudur (Öztürk,2003:262).

Sanayi devrimiyle birlikte insanların işyeri gibi birçok alanda toplu olarak bulunmaları çatışma konusunda çeşitli görüşlerin ortaya atılmasına yol açmıştır. Bu bağlamda Marx, farklı toplumlar ve sınıflar arasındaki çatışmaların tarih ile başladığını ve ekonomik nedenlere dayandığını savunmuştur (Özkalp,2004:135). Bununla birlikte Weber, sınıf çatışmasının yalnızca ortak hareket etme ve dayanışma şuurunun bir hayli yüksek olduğu ortamlarda geliştiğini savunmaktadır (Öngen,2009:86). Modern toplumlarda çatışmayı inceleyen Simmel ise çatışmayı bir gruptaki bütünleyici güç olarak tanımlamışırır (Simmel,1999:34).

\section{Örgütsel Çatışma}

Bir takım amaçlar boyutunda bir araya gelmiş insanların gerekli fiziksel öğelerle oluşturdukları yapı örgüt olarak tanımlanmaktadır (Atak,2005:59). Örgütleri meydana getiren bireyler ortak bir ya da birden fazla amaca ulaşmak için çaba sarf etmektedirler. Belirlenen amaçlara ulaşmak için farklı yolların kullanılmak istenmesi ya da bir takım görüş farklılıkları örgütlerde çatışma olgusunun ortaya çıkmasına neden olmaktadır. 
Bu itibarla örgütsel çatışma; örgüt içerisinde, kişiler ya da gruplar arasında kıt kaynakların pay edilmesi ya da etkinliklerin dağılımı ile yine bu kişiler veya gruplar arasındaki statü, amaç, değer ya da alg1 farklılıklarından ortaya çıkan anlaşmazlık veya uyuşmazlıktır (Solmuş,2004:37). Bir başka deyişle örgütsel çatışma, kişiler ve grupların aynı amaç için bir arada faaliyet yürütürken ortaya çıkan sorunlarından kaynaklanan ve normal faaliyetlerin duraksamasına ya da karışmasına neden olan olaylardir (Eren, 2008:609).

Örgütlerde sık olarak görülen çatışmalar, örgütün ne derece büyük olduğu, hedeflerin ne kadar farklılaştığı, iş bölümünün nasıl yapıldığı ve ortaya ne tür kişisel sorunların çıktığı gibi birçok sebebe ve şarta bağlı olmaktadır. Bu bağlamda örgütsel çatışmanın nedenleri genel olarak, işler arası fonksiyonel karşılıklı bağlılık, belirli kaynakların paylaşılması, amaç ve algılama farklılıkları, yönetim alanına ilişkin belirsizlik, iletişim noksanlıkları, statü farklılıkları, yönetici tarzları arasındaki farklılıklar, çıkar farklılıkları, kişilik farklılıkları, değişen koşulların öngördüğü yeni nitelikler, işçiişveren ilişkilerindeki kutuplaşmalar, örgüt içi güç mücadelesi olarak sıralanabilmektedir (Koçel, 2013:651-653).

Tarihsel süreç içerisinde işletmelerin büyümesi ve çeşitlenmesi ile birlikte faklı dönemlerde örgüt algısında ve dolayısıyla örgütsel çatışma algısında değişmeler gözlemlenmiştir. Geleneksel işletme yönetimi çağında çatışma, istenmeyen ve uzaklaştırılması gereken bir nesne olarak değerlendirilmektedir. Yöneticiler örgütü olumsuz etkileyen ve işleyişini bozan çatışmayı ortadan kaldırmakla görevlidir (Şahin vd.,2006:555). Neoklasik dönem adı da verilen davranışsal dönem de ise örgütsel çatışmanın doğal ve kaçınılmaz olduğu görüşü hakim olmakta ve bu olgunun yok edilmesi yerine, onu kabul ederek ondan faydalanma görüşü kabul görmüştür (Yatkın,2008:13). Modern işletme yönetimi anlayışında çatışma örgütlere bir takım yenilik ve farklı bakış açıları getirmesi nedeniyle olumlu bir olgu olarak değerlendirilmektedir. Bu yaklaşımda çatışmalar kaçınılmazdır ve açık sistemler olarak görülen örgütlerde belirli bir düzeyde çatışma olması zorunludur (Koçel,2013:646).

Örgütsel çatışmaya ilişkin literatür incelendiğinde söz konusu çatışmanın birçok açıdan sınıflandırıldığı görülmektedir. Bu itibarla genel olarak örgütsel çatışmayı, işlevselliğine, ortaya çıkışına, taraflarına ve örgütteki yerine göre sınıflandırmak mümkündür. Özellikle taraflarına göre çatışmada örgüt içindeki bireylerin birbirleriyle çatışması, grupların birbirleriyle çatışması ve örgütlerin birbirleriyle çatışmasına sıkça rastlanmaktadır. Ayrıca örgütteki yerine göre çatışmada dikey, yatay ve emir komuta - kurmay çatışması önemlidir (Koçel, 2013:647-650, Şimşek ve Çelik, 2014:152-156).

Örgütsel çatışma yönetimi üzerine yapılan bir araştırmada yöneticilerin zamanlarının \%20 den fazlasını çatışma sonucunda meydana gelen sorunları çözmek için kullandıkları ve çatışma yönetiminin yöneticilerin işleri arasında yedinci sırada bulunduğunu ortaya koymaktadır (Ceylan vd., 2000:40).

Çatışma yönetimi, çatışmanın olumsuz yönlerini azaltırken, olumlu yönlerini de arttırma süreci olarak tanımlanabilmektedir. Çatışma yönetiminin amacı, örgütlerde etkinlik, performans gibi öğrenme ve grup kazanımlarını geliştirmektir (Sasikala vd., 2014:52).

Örgütsel çatışmanın yönetilmesi bakımından uygulamaya yönelik bir takım stratejiler geliştirilmiştir. Söz konusu literatür incelendiğinde genel kabul gören stratejileri geliştiren ve bilime kazandıran Western Kentucky Üniversitesi'nden Afzalur Rahim olmuştur. Ayrıca ROCI (Rahim Organizational Conflict Inventory) olarak adlandırdığ 1 bir örgütsel çatışma ölçeği de geliştirmiştir.

Bütünleştirme stratejisi, taraflar arasında işbirliğini içermesi gerekmektedir (Rahim, 2001:28). Bütünleştirmede taraflar, hem kendilerinin hem de karşı tarafın isteklerini göz önüne alarak çözüme ulaşmayı amaçlamaktadır. Bu stratejide açık iletişim yaşanır ve her iki tarafında kazanması temeli esas alınır (Üngüren, 2008:891). 
Ödün verme olarak da isimlendirilen uyma stratejisi, çatışma içindeki taraflardan birinin kendi ihtiyaçlarını bir kenara bırakarak karşı tarafin ihtiyaçlarını ön plana almasına dayanır. Bu strateji, karşı tarafla olan ilişkinin korunması ve sürdürülmesine verilen önemin, kendi ihtiyaçlarının karşılanmasına verilen önemden daha yüksek olduğu hallerde kullanılması beklenmektedir (Karcığlu vd., 2012:81).

Hükmetme stratejisi, kişinin başka bir kişinin pozisyonunu elde etmek için güç kullanmasıdır. Bu stratejiyi uygulayan bir birey amacına ulaşmak için her şeyi yapar ve karşı tarafın ihtiyaçlarını ve beklentilerini genellikle görmezden gelir. (Rahim, 2010:4).

Kaçınma stratejisi, çatışmadan olabildiğince kaçınmak, çatışma yokmuş gibi davranmak olarak tanımlanabilmektedir. Bu strateji, güç sahibi kişilerle çatışan düşük enerjili bireyler için bir seçenek olabilir ve düşük güç sahibi birey için riski azaltma yolu olarak görülebilir (Jandt, 2016:23).

Uzlaşma stratejisini, karşılıklı ödün verme stratejisi olarak adlandırmak da mümkündür (Karip, 2013:68). Bu strateji de çatışmanın her iki tarafı da bir takım taleplerinden vazgeçerek sonuç elde edilmesine katkıda bulunur. Ancak bu stratejinin uygulanabilmesi için her iki tarafında bir takım taleplerden taviz verme istekliliğini göstermesi gerekmektedir.

\section{Yabancılaşma}

Yabancılaşma kavramı günlük hayatta sıkça karşılaşılan bir kavramdır. Birçok bilim dalının konusunu oluşturan yabancılaşma, insanların davranışlarını da etkilemektedir. Bu bağlamda sözlük anlamı olarak yabancılaşma, 'Belli tarihsel şartlarda insan ve toplum etkinlikleri ürünlerinin, bu etkinliklerden bağımsız ve bunlara egemen olan ögelerin değişik biçimde kavranması"' (Türkçe Sözlük, 2010:2496-2497) olarak tanımlanmıştır. Ayrıca bireysel açıdan değerlendirildiğinde yabancılaşma, 'kişinin içinde yaşadığı topluma, kültürel değerlere ve rol dağılımına karşı ilgisinin kaybolması, değer ve normları anlamsız görmesi, kendisini güçsüz ve yalnız hissetmesi durumu' (Demir ve Acar, 997:217) olarak tanımlanmıştır.

Tarihsel süreç içerisinde o günün şartlarına göre yabancılaşma kavramından ne anlaşıldığ değişiklik göstermiş ve bir takım yeni olgulara dayanarak gelişmiştir. Hegel'e göre yabancılaşma, insanın fiziksel ve ruhsal varlıkları arasında ortaya çıkan ayrımın bir sonucudur (Ofluoğlu ve Büyükyılmaz, 2008:115). Marx yabancılaşmayı, materyalist bir çerçevede iktisat ile ilişkilendirmiştir (Aydoğan, 2015:273). Alman Sosyolog Simmel ise yabancılaşmayı, modern yaşamda kişinin yalnızlığı, rekabet etme zorunluluğu ve yalnız başına ayakta durma ihtiyacı sonucunda kişinin bilinci ile duygusal durumu arasında mesafe oluşturması olarak açıklamıştır (Can,2016:231). İşletme bilimi açısından yabancılaşmanın konusu, bir işyerinde çalışan işgörenin bir takım nedenler dolayısıyla işyerine, işverenine ya da iş arkadaşlarına karşı uzaklaşması ve aidiyet bağlarının azalması veya tamamen kopmasidir.

Yabancılaşmayı üst bir kavram olarak oluşturan alt boyutların tanımlanması konusu incelendiğinde Melvin Seeman'ın ortaya koyduğu, güçsüzlük, anlamsızlık, normsuzluk, yalıtılmışlık ve kendine yabancılaşma başlıklarının literatürde genel kabul gördüğü anlaşılmaktadır (Seeman, 1959:783791).

$\mathrm{Bu}$ bağlamda güçsüzlük, kişinin karşılanmasını düşündüğü beklentilerinin kendisince tayin edilememesi ve sonucunu değiştirebilmek için yapacak hiçbir şeyi olmadığını düşünmesi olarak tanımlanabilir (Ofluoğlu ve Büyükyılmaz, 2008:133). Anlamsızlık, kişinin neye inanması gerektiği konusunda yeteri kadar bilgilendirilmemesi ve bireysel olarak karar verirken kişinin doğruları ile toplumun doğrularının birbirini tamamlaması olarak tanımlanmıştır (Seeman, 1983:173). Literatürde bazı kaynaklarda kuralsızlık olarak adlandırılan normsuzluk ise bireylerin değer yargılarının olmaması 
ya da var olan bu yargıları ortaya koyamaması gibi çeşitli nedenlerle genellikle toplumsal kuralları benimsememesi olarak tanımlanmaktadır (Elma, 2003:32).

Yalıtılmışlık, toplumun bireyin üstüne bir takım yüksek değerler yüklemesi sonucu bu amaç ve hedeflerin kişiler için herhangi bir anlam ifade etmemesi durumu olarak tanımlanmaktadır (Seeman, 1959:789). Kişinin içinde bulunduğu fiziksel çevreden kaçınması olarak da tanımlanan yalıtılmışlıkta bu uzaklaşmanın nedenleri, bireyin psikolojik durumu ve çevrenin durumu olarak açıklanabilmektedir (Elma, 2003;37). Son olarak kendine yabancılaşma, kişinin yapmak istedikleri ile gerçekte yaptıkları arasında bir bağ kuramaması ile başarıdan doğan mutluluğu içselleştirememesi olarak açıklanmaktadır (Eryılmaz ve Burgaz, 2011:275).

\section{YÖNTEM}

$\mathrm{Bu}$ çalışmanın amacı, örgütsel çatışma ile yabancılaşma arasında bir ilişkinin olup olmadığı ile varsa hangi boyutlarda olduğunu tespit etmek ve bu sonuçlar 1şı̆̆ında örgütlere ilgili konuların yönetiminde yardımcı olmaktır. Bu amaçla bir bakanlığın merkez teşkilatında görev yapan çalışanlar arasından basit tesadüfi örneklem yönetimiyle kişiler seçilmiştir.

\section{Veri Toplama Araçları}

Araştırmada kullanılan verilerin toplanması anket yöntemiyle sağlanmıştır. Söz konusu anket çoktan seçmeli sorulardan meydana gelmiş olup, üç bölümden oluşmaktadır. Ayrıca ankette 5'li likert ölçeği; 1. Hiç Katılmıyorum, 2. Katılmıyorum, 3. Kararsızım, 4. Katılıyorum, 5. Çok Katılıyorum) kullanılmıştır. Anket formundaki birinci bölümde ankete katılan çalışanların demografik özellikleri yer almaktadır. İkinci bölümde çatışma ve üçüncü bölümde yabancılaşma başlıkları altında sorular bulunmaktadır. Anketin uygulanması için internet üzerinden form oluşturulmuş ve bu sorulara ilişkin web bağlantısı çalışanlara gönderilerek cevapları toplanmıştır.

\section{Verilerin Analizi}

Anket çalışması sonrasında elde edilen ham veriler, Statistical Package for the Social Sciences (SPSS 26) programı kullanılarak analiz edilmiştir. Bu süreçte korelasyon ve basit regrasyon analizleri ile $t$ testi metodu uygulanmıştır.

Anket formunun ikinci bölümünde yer alan çatışma ölçeği, Rahim (1983) tarafindan ortaya konulmuş olup, kendisi tarafindan tekrar geliştirilmiştir (Rahim Organizational Conflict Inventory-II / ROCI-II 2001). Ölçek için Uysal (2014) tarafindan yapılan çalışmada güvenilirlik 0,79 olarak tespit edilmiş iken, bu çalışmada söz konusu oran 0,88 olarak bukunmuştur. Anket formunun üçüncü bölümünde kullanılan örgütsel yabancılaşma ölçeği ise Minibaş (1993) tarafindan oluşturulmuş ve güvenilirliği kendisi tarafından tekrar test edildikten sonra banka personelinin yabancılaşma düzeyi ile ilgili doktora tezinde kullanılmıştır. Ölçeğin yapılan güvenilirlik analizinde Cronbach's Alpha katsayısı 0,96 olarak hesap edilmiştir.

\section{Örneklem/Çalışma Grubu/Katılımcılar}

Araştırmanın evrenini, Türkiye Cumhuriyeti Hükümet Sistemi'nde yer alan ve bir takım yasal dayanaklar ile görev üstlenen bir bakanlığın merkez teşkilatında görev alan tüm unvan ve görev sınıflarından toplam 3675 çalışan oluşturmaktadır. Araştırma yapılan bakanlık, isminin gizli tutulması şartı ile çalışma yapılmasına izin verdiğinden ismi açıklanamamaktadır. Araştırma için, söz konusu bakanlıkta yer alan 19 ana hizmet biriminde bulunan çalışanlar arasından tüm unvan ve hizmet sınıflarından 404 çalışan gelişigüzel seçilmiştir. 
Örneklem büyüklüğünü hesaplamak için Yamane (2001: 116-117) tarafindan ortaya konulan formül kullanılmıştır; n: Örneklem büyüklüğü, N: Evren büyüklüğü, z: Standart normal dağılım tablosu değeri, d: Duyarlılık, p: Bir çalışanın örneğe seçilme olasılığı, q: Bir çalışanın örneğe seçilmeme olasılığı

$$
\begin{gathered}
\mathrm{n}=\frac{N \cdot z^{2} \cdot p \cdot q}{N \cdot d^{2}+z^{2} \cdot p \cdot q} \\
\mathrm{n}=\frac{3675 \cdot 1,96^{2} \cdot 0,5 \cdot 0,5}{3675 \cdot 0,05^{2}+1,96^{2} \cdot 0,5 \cdot 0,5} \\
\mathrm{n}=348 \text { çalışan }
\end{gathered}
$$

Bu araştırma için 3675 kişilik bir evren büyüklüğünde en az 348 örneklem sayısına ihtiyaç olduğu ortaya konulmaktadır. Araştırmada kullanılan örneklem sayısının 404 olduğu göz önüne alındığında söz konusu sayının yeterli olduğu görülmektedir.

\section{Hipotezler}

Araştırmada aşağıdaki hipotezler test edilmiştir;

H1: Çatışma ile örgütsel yabancılaşma arasında anlamlı bir ilişki vardır.

H2: Çatışmanın örgütsel yabancılaşma üzerinde anlamlı bir etkisi vardır.

H3: Cinsiyet ile çatışma arasında anlamlı bir farklılık yoktur.

H4: Cinsiyet ile yabancılaşma arasında anlamlı bir farklılık yoktur.

H5: Medeni durum ile çatışma arasında anlamlı bir farklılık yoktur.

H6: Medeni durum ile yabancılaşma arasında anlamlı bir farklılık yoktur.

\section{BULGULAR}

Araştırmada ilk olarak araştırmaya katılan çalışanların demografik bilgilerine yönelik bulgulara yer verilmiş, ikinci olarak ölçekte yer alan ifadelerin tanımlayıcı istatistiklerine yer verilmiştir. Son olarak araştırmanın amacı doğrultusunda oluşturulan hipotezlerin test sonuçları yer almaktadır.

\section{Demografik Bulgular}

Araştırmaya katılanların demografik bilgilerine ilişkin vermiş olduğu yanıtlar aşağıda gösterilmiştir;

Tablo 1: Yaş Dağılımı

\begin{tabular}{lll}
\hline & $\mathrm{N}$ & $\%$ \\
\hline $18-25$ yaş & 9 & 2,2 \\
\hline $26-30$ yaş & 54 & 13,4 \\
\hline $31-35$ yaş & 129 & 31,9 \\
\hline $36-40$ yaş & 112 & 27,7 \\
\hline
\end{tabular}




\begin{tabular}{lll}
\hline $41-45$ yaş & 49 & 12,1 \\
\hline $46-50$ yaş & 26 & 6,4 \\
\hline 51 ve üstü & 25 & 6,2 \\
\hline Toplam & 404 & 100,0
\end{tabular}

Araştırmaya katılan çalışanların yaş dağılımlarında büyük çoğunluğun 31-35 yaş aralığında olduğu tespit edilmiştir. İkinci büyük çoğunluğun 36-40 yaş aralığında, üçüncü büyük çoğunluğun ise 26-30 yaş aralığında olduğu görülmektedir.

Tablo 2: Cinsiyet Dă̆gllımı

\begin{tabular}{lll}
\hline & $\mathrm{N}$ & $\%$ \\
\hline Kadın & 149 & 36,9 \\
\cline { 2 - 3 } Erkek & 255 & 63,1 \\
\hline Toplam & 404 & 100,0 \\
\hline
\end{tabular}

Araştırmaya katılan çalışanların cinsiyet dağılımlarında \%36,9'unun kadın, \%63,1'inin ise erkek olduğu görülmekte olup, büyük çoğunluğu erkekler oluşturmaktadır.

Tablo 3: Medeni Durum Dağılımı

\begin{tabular}{llll}
\hline & & $\mathrm{N}$ & $\%$ \\
\hline & Evli & 291 & 72,0 \\
\cline { 2 - 3 } & Bekar & 113 & 28,0 \\
\cline { 2 - 3 } & Toplam & 404 & 100,0 \\
\hline
\end{tabular}

Araştırmaya katılan çalışanların medeni durum dağılımlarında \%72'sinin evli, \%28'inin ise bekar olduğu görülmektedir. Ankete katılanların yaklaşık olarak dörtte üçü evlidir.

Tablo 4: Ĕ̆itim Düzeyi Dă̆ılımı

\begin{tabular}{lll}
\hline & $\mathrm{N}$ & $\%$ \\
\hline İlköğretim/Ortaokul & 8 & 2,0 \\
\hline Lise & 28 & 6,9 \\
\hline Önlisans & 28 & 6,9 \\
\hline Lisans & 247 & 61,1 \\
\hline Yüksek lisans & 86 & 21,3 \\
\hline Doktora & 7 & 1,7 \\
\hline Toplam & 404 & 100,0 \\
\hline
\end{tabular}


Araştırmaya katılan çalışanların eğitim düzeyine bakıldığında büyük çoğunluğun lisans mezunu olduğu görülmektedir. İkinci büyük çoğunluğun yüksek lisans, üçüncü büyük çoğunluğun ise lise ve önlisans mezunları olduğu tespit edilmiştir.

Tablo 5: Mevcut İ̧̧yerindeki Çalışma Süresi

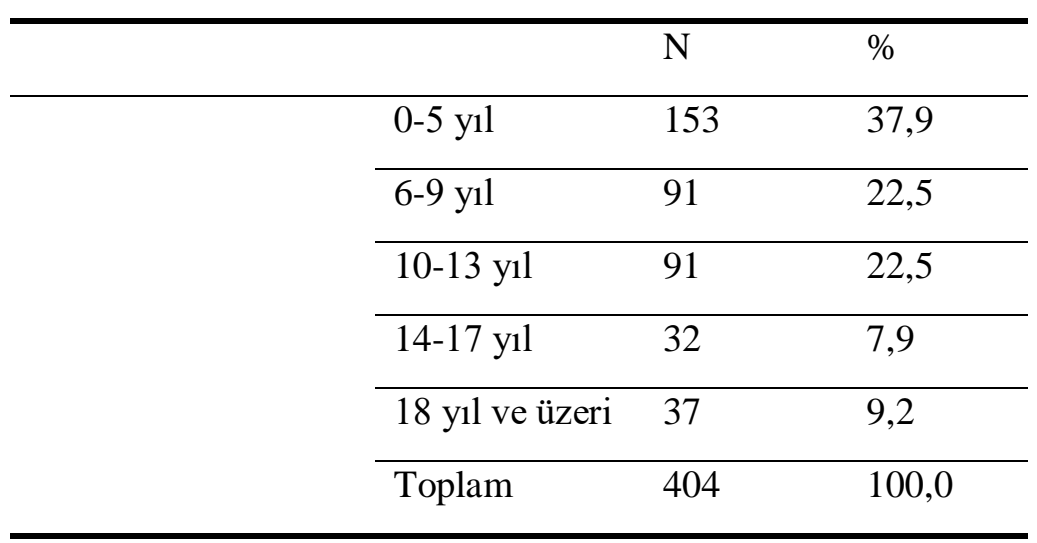

Araştırmaya katılan çalışanların mevcut işyerlerindeki çalışma sürelerine bakıldığında büyük çoğunluğun 0-5 yıldır mevcut işyerine çalıştıkları görülmektedir. İkinci büyük çoğunluğun 6-9 yıl ve 10-13 y1l olduğu, üçüncü büyük çoğunluğun ise 18 y1l ve üzeri olduğu tespit edilmiştir.

\section{Hipotezlerin Test Edilmesi}

Araştırmaya konu olan çalışanlar üzerinde yapılan anket çalışmasının, hem çatışma ölçeği hem de yabancılaşma ölçeğinde kullanılan sorulara verilen cevaplar; (1) Hiç katılmıyorum, (2) Katılmıyorum, (3) Kararsızım, (4) Katılıyorum, (5) Çok Katılıyorum olacak şekilde 5'li Likert olarak yapılandırılmıştır. Bu kapsamda söz konusu ölçeklere ilişkin ortalama ve standart sapma değerleri aşağıda gösterilmiştir;

Tablo 6: Ölçeklerin Ortalama ve Standart Sapma Değerleri

\begin{tabular}{lll}
\hline & Ort. & SS \\
\hline Çatışma & 3,43 &, 465 \\
\hline Yabancılaşma & 2,65 &, 746 \\
\hline
\end{tabular}

Örgütsel çatışma ve yabancılaşma düzeyine ilişsin elde edilen ortalama değerler incelendiğinde çatışma algısının 3,43 ve yabancılaşma düzeyinin ise 2,65 olduğu tespit edilmiştir. Bu sonuç kapsamında çalışanların çatışma algısının katılıyorum; yabancılaşma düzeyinin ise kararsızım yönünde olduğu görülmektedir.

Tablo 7: Çatışma ve Yabancılaşma Arasındaki Korelasyon Analizi

\begin{tabular}{llll}
\hline & \multicolumn{3}{c}{ Çatışma } \\
\hline Yabancılaşma & \multicolumn{1}{c}{ r } &, $164^{* *}$ \\
\cline { 2 - 3 } & & p &, 001
\end{tabular}

** ve * sırasıyla \% 1 ve \% 5 düzeyinde istatistiki anlamlılı̆g (2-kuyruklu) temsil etmektedir. 
Çatışma ile örgütsel yabancılaşma arasındaki korelasyon analizi sonucunda çatışma ile örgütsel yabancılaşma arasında pozitif yönde anlamlı bir ilişki olduğu tespit edilmiştir. H1 kabul edilmiştir.

Tablo 8: Çatışmanın Yabancılaşmayı Etkilemesine İlişkin Basit Regresyon Analizi

\begin{tabular}{lllllllllll}
\hline $\begin{array}{l}\text { Bağımsız } \\
\text { Değişken }\end{array}$ & $\begin{array}{l}\text { Bağımı ı } \\
\text { Değişken }\end{array}$ & $\mathbf{B}$ & $\begin{array}{l}\text { Std. } \\
\text { Hata }\end{array}$ & $(\boldsymbol{\beta})$ & $\mathbf{t}$ & $\mathbf{R}$ & $\mathbf{R}^{2}$ & $\mathbf{F}$ & $\boldsymbol{p}$ \\
\hline Çatışma & Yabancılaşma &, 102 &, 031 &, 164 & 3,334 &, 164 &, 027 & 11,113 &, 00 \\
\hline
\end{tabular}

Örgütsel çatışmanın, örgütsel yabancılaşma üzerindeki etkisine yönelik yapılan basit regresyon analizi sonucuna göre çatışma ölçeğinin $\left(r^{2}=, 027, p<0,01\right)$ yabancılaşma üzerinde pozitif yönde ve anlamlı düzeyde bir etkiye sahip olduğu görülmektedir. Başka bir ifade ile çatışma, yabancılaşma düzeylerindeki toplam varyansın \%2,7'sini açıklamaktadır. H2 kabul edilmiştir.

Tablo 9: Çatışmanın, Yabancılaşmanın Alt Boyutlarını Etkilemesine İlişkin Çoklu Regresyon Analizi

\begin{tabular}{|c|c|c|c|c|c|c|c|c|c|c|}
\hline \multirow{2}{*}{\multicolumn{2}{|c|}{ Model }} & \multicolumn{2}{|c|}{$\begin{array}{l}\text { Standartlaştırıl- } \\
\text { mamış } \\
\text { Katsayılar }\end{array}$} & \multirow{2}{*}{$\begin{array}{l}\text { Standartlaş- } \\
\text { tırılmış } \\
\text { Katsayılar } \\
\beta\end{array}$} & \multirow[t]{2}{*}{ t } & \multirow[t]{2}{*}{$\mathbf{F}$} & \multirow[t]{2}{*}{$\bar{p}$} & \multirow[t]{2}{*}{$\mathbf{R}$} & \multirow[t]{2}{*}{$\mathbf{R}^{2}$} & \multirow[t]{2}{*}{$\begin{array}{l}\text { Düz. } \\
\mathbf{R}^{2}\end{array}$} \\
\hline & & B & SH & & & & & & & \\
\hline \multirow[t]{2}{*}{1} & Sabit & 3,068 & ,087 & & 35,427 & 19,122 & ,000 & 213 & ,045 & ,043 \\
\hline & Güçsüzlük &, 129 & ,029 & ,213 & 4,373 & & ,000 & & & \\
\hline \multirow[t]{3}{*}{2} & Sabit & 2,991 & ,091 & & 32,817 & 12,941 & ,000 & ,246 & ,061 & ,056 \\
\hline & Güçsüzlük & ,089 & ,033 & ,147 & 2,673 & & ,008 & & & \\
\hline & Normsuzluk & ,078 & ,031 & ,140 & 2,549 & & ,011 & & & \\
\hline \multirow[t]{4}{*}{3} & Sabit & 3,020 & ,092 & & 32,873 & 10,091 & 2,000 & 265 & ,070 & ,063 \\
\hline & Güçsüzlük &, 135 & ,040 & ,223 & 3,369 & & ,001 & & & \\
\hline & Normsuzluk & ,098 & ,032 & ,176 & 3,063 & & ,002 & & & \\
\hline & Anlamsızlık &,- 072 & ,035 &,- 139 & $-2,046$ & & ,041 & & & \\
\hline
\end{tabular}

Tablo 9'da bağımsız değişken olan çatışmanın, bağımlı değişken olan yabancılaşmanın alt boyutları olan güçsüzlük, anlamsızlık, normsuzluk, kendine yabancılaşma, çevreden uzaklaşma ve işten uzaklaşma üzerindeki etkisi incelenmektedir. Buna göre, hiyerarşik regresyon analizinin 1. aşamasında çatışmanın, güçsüzlük üzerinde üzerinde pozitif yönde ve anlamlı bir etkisi olduğu $(\beta=, 213, p<0.01)$ görülmektedir.

Analizin 2. aşamasında bağımsız değişken olan çatışmanın güçsüzlük ve normsuzluk üzerindeki etkisi değerlendirilmiştir. Buna göre çatışmanın güçsüzlük $(\beta=, 147, p<0.05)$ ve normsuzluk üzerinde $(\beta=, 140, \mathrm{p}<0.05)$ pozitif ve anlamlı bir etkisi olduğu görülmektedir.

Analizin 3. ve son aşamasında ise çatışmanın güçüzzlük, normsuzluk ve anlamsızlık üzerindeki etkisi birlikte değerlendirilmiştir. Değişkenler birlikte ele alındığında, çatışmanın tüm değişkenleri etkilediği görülmüştür. Burada çatışmanın güçsüzlük $(\beta=, 223, \mathrm{t}=3,369, \mathrm{p}<0.01)$, normsuzluk $(\beta=, 176$, 
$\mathrm{t}=3,063, \mathrm{p}<0.01)$ ve anlamsızlık $(\beta=-, 139, \mathrm{t}=-2,046, \mathrm{p}<0.05)$ üzerinde üzerinde anlamlı bir etkisi olduğu tespit edilmiştir.

Tablo 10: Cinsiyet ile Çatışma ve Yabancılaşma Arasındaki Karşılaştırmanın Bağımsız Örneklem tTesti

\begin{tabular}{lllllll}
\hline & Cinsiyet & $\mathrm{N}$ & Ort. & SS & $\mathrm{F}$ & $\mathrm{t}$ \\
\hline Çatışma & Kadın & 149 & 3,46 &, 491 & \multirow{2}{*}{, 017} & \multirow{2}{*}{, $803^{*}$} \\
\cline { 2 - 5 } & Erkek & 255 & 3,42 &, 450 & & \\
\hline Yabancılaşma & Kadın & 149 & 2,65 &, 745 & \multirow{2}{*}{, 000} &,$- 081^{*}$ \\
\cline { 2 - 5 } & Erkek & 255 & 2,65 &, 748 & & \\
\hline
\end{tabular}

$* \mathrm{p}>0,05$

Cinsiyet ile örgütsel çatışma ve yabancılaşma arasındaki karşılaştırma sonucunda 0,05 düzeyinde anlamlı bir farklılık olmadığı tespit edilmiştir. Başka bir ifade ile çalışanların cinsiyetinin çatışma ve yabancılaşma düzeyleri üzerinde herhangi bir etkisi olmadığı tespit edilmiştir. H3 ve H4 kabul edilmiştir.

Tablo 11: Medeni Durum ile Çatışma ve Yabancılaşma Arasındaki Karşılaştırmanın Bă̆ımsız Örneklem t-Testi

\begin{tabular}{|c|c|c|c|c|c|c|}
\hline & Cinsiyet & $\mathrm{N}$ & Ort. & $\overline{S S}$ & $F$ & $\bar{T}$ \\
\hline \multirow[t]{2}{*}{ Çatışma } & Evli & 291 & 3,44 & ,459 & \multirow[t]{2}{*}{,063 } & \multirow[t]{2}{*}{, $398^{*}$} \\
\hline & Bekar & 113 & 3,42 & ,484 & & \\
\hline \multirow[t]{2}{*}{ Yabancılaşma } & Evli & 291 & 2,65 & ,764 & \multirow[t]{2}{*}{,878 } & \multirow[t]{2}{*}{, $066^{*}$} \\
\hline & Bekar & 113 & 2,65 & ,701 & & \\
\hline
\end{tabular}

$* \mathrm{p}>0,05$

Medeni durum ile örgütsel çatışma ve yabancılaşma arasındaki karşılaştırma sonucunda 0,05 düzeyinde anlamlı bir farklılık olmadığı tespit edilmiştir. Başka bir ifade ile çalışanların medeni durumlarının çatışma ve yabancılaşma düzeyleri üzerinde herhangi bir etkisi olmadığı tespit edilmiştir. H5 ve H6 kabul edilmiştir.

\section{SONUC}

Araştırmanın ana sorusunu oluşturan çatışma ile yabancılaşma arasındaki ilişkinin tespit edilmesine yönelik yapılan korelasyon analizi sonucunda bağımsız değişken olan çatışma ile, bağımlı değişken olan yabancılaşma arasında \% 16,4 oranında ilişki olduğu tespit edilmiştir. Söz konusu veriden yola çıkarak araştırmanın yapıldığı örgütte çatışmanın bulunmuş olması yabancılaşma olgusunun da var olduğu sonucunu ortaya koymaktadır. Ayrıca ilgili analizdeki ilişkinin pozitif yönlü olması, çatışmanın arttığı bu örgütte, yabancılaşmanın da ilişki oranında arttırdığını ortaya koymaktadır. Aynı şekilde, söz konusu örgütte yabancılaşmanın ortaya çıkması, çatışmanın da ortaya çıkması anlamına gelmektedir. Ayrıca yabancılaşmanın arttığı bu örgütte, çatışmanın da ilişki oranında arttırdığı ortaya konulmaktadır.

Araştırmanın bir diğer ana sorusu olan çatışmanın yabancılaşmayı etkileyip etkilemediğinin açıklanması bakımından yapılan basit regresyon analizi sonucunda çatışmanın, yabancılaşmayı etkilediği tespit edilmiştir. Şöyle ki, her iki değişken arasındaki anlamlılık düzeyi (p) incelendiğinde 
bağımsız değişken olan çatışmanın, bağımlı değişken olan yabancılaşmayı \% 2,7 oranında etkilediği anlaşılmaktadır. Ayrıca ilişkinin yönünün pozitif olması (t) bağımsız değişkenin değişmesi durumunda bağımlı değişkenin de aynı yönde değişeceğini göstermektedir. Bu bağlamda çalışmanın yürütüldüğü kamu kuruluşunda ortaya çıkan bir çatışmanın artması, yabancılaşmanın da etkilenme oranı düzeyinde artmasına neden olur. Aynı şekilde söz konusu örgütte çatışma düzeyinin azalması, yabancılaşmanın da etkilenme oranı kadar azalmasina neden olur.

Demografik değişeknelrin çatışma ve yabancılaşmayı etkileyip etkilemediğinin tespit edilmesine yönelik yapılan çalışmada ise, cinsiyetin çatışma ve yabancılaşma algısı üzerinde herhangi bir etkisinin olmadığ 1 tespit edilmiştir. Araştırmaya katılan kadın çalışanların çatışmaya ilişkin verdiği cevapların ortalaması 3,49 ve erkeklerin verdiği cevapların ortalaması ise 3,42'dir. Her iki rakamda Kaplanoğlu (2014) tarafından yapılan araştırma ile berlirlenen 5'li Likert ölçeğine göre aritmetik ortalamaların değerlendirme aralığına göre 'Katılıyorum' seviyesine isabet etmektedir. Ayrıca yabancılaşma algısı üzerinde ise her iki cinsiyet grubunda da 2,65 ortalama rakamı tespit edilmiş olup, 'Kararsızım' seviyesine isabet etmektedir. Yapılan $t$ testi sonunda ise her iki değişkende de anlamlı bir farklılık olmadığı sonucuna ulaşılmıştır.

Bir diğer demografik veri olan medeni durumun incelenmesi sonucunda ankete katılan çalışanlardan evli olanların çatışmayı algılama ortalaması 3,44, bekar olanların ise 3,42'dir. Her iki rakam da 5'li Likert ölçeğinde 'Katılıyorum' seviyesine denk gelmekte olup, çalışanların medeni durumunun, çatışma algısı üzerinde herhangi bir etkisinin olmadığı sonucunu ortaya koymaktadır. Aynı şekilde medeni durum bağlamında çalı̧̧anların yabancılaşma algısı üzerine yapılan çalışmada her iki grupta da 2,65 ortalama rakamına ulaşılmıştır. Söz konusu ortalama rakam 'Kararsızım' seviyesine isabet etmektedir. Ayrıca yapılan t testi sonunda ise her iki değişkende de anlamlı bir farklılık olmadığ sonucuna ulaşılmış olup, araştırmaya konu olan kamu kuruluşunda çalışanların medeni durumlarının yabancılaşmayı algılama seviyelerinde herhangi bir katkısının olmadığı sonucuna ulaşılmıştır.

Konu ile ilgili literatür incelendiğinde her iki değişken arasındaki ilişkinin doğrudan incelendiği bir çalışmaya rastlanmamıştır. Bu bağlamda ilgili değişkenler ayrı ayrı değerlendirilmiştir. Yılmaz (2016) tarafından yapılan çalışmada çatışma yönetimi ile örgütsel vatandaşlık davranışı arasında pozitif yönde anlamlı bir ilişki tespit edilmiştir. Ayrıca Haqe (2019) tarafından yapılan bir diğer araştırmada bir takım liderilik rollerinin, örgütsel çatışmayı etkilediği sonucuna ulaşılmıştır. Çetinkaya (2019)'nın perakende sektörü üzerinde gerçekleştirdiği araştırmada psikolojik dayanıklılık ile örgütsel yabancılaşma aradında negatif yönlü anlamlı bir ilişik olduğu sonucuna ulaşılmıştır.

Örgütsel davranış konusunun, bir örgüte üye olan insanların davranışlarının ilgili örgütle ilişkilendirilmesi olarak değerlendirildiğinde, söz konusu davranışları etkileyen bir çok değişken ve faktör bulunmaktadır. Bu faktör ve değişkenlerin örgütü etkilemesi kaçınılmazdır. Bu bağlamda literatürde örgütsel davranış tarzlarının birbirlerini etkilemeleri bakımından yapılan sayısız çalışma ortaya konulmuştur. Bu bağlamda örgütsel çatışma ve yabancılaşma alanında gerçekleştirilen çalışmalar değerlendirildiğinde örgütte yer alan bireyleri söz konusu örgüte uzaklaştıran, örgüt ile olan ilişkilerini olumsuz etkileyen bir çok etken aidiyetin azalmasına neden olmaktadır. Bu çalışma kapasamında da yapılan araştırmada aynı sonuç elde edilmiştir.

\section{ÖNERILER}

Yapılan araştırma kapsamında elde edilen veriler ışığında, çatışmanın yabancılaşmayı etkilediği ve söz konusu etkinin aynı yönlü olduğu sonucuna istinaden, bulundukları örgütlerde çatışmanın yönetilmesi çerçevesinde çalışma yapacak olan yöneticilerin aynı zamanda yabancılaşma konusunu da yönetecek olduğunu bilmesi ve bu kapsamda ilgili faaliyetleri yürütmesi önerilmektedir. İlgili 
yöneticilerin, örgütlerinde gerçekleştirecekleri planlama ve uygulama süreçlerinde etkinlik ve verimliliği sağlamaları bakımından araştırma verileri ışığında ortaya konulan sonuçları göz önünde bulundurmaları tavsiye edilmektedir. Ayrıca çalışma sonuçları yöneticiler tarafindan, finansal kaynaklar, insan kaynakları ve zamandan tasarruf edilmesine katkı sağlaması bakımından göz önünde bulundurulmalıdır.

Örgütsel çatışma ve örgütsel yabancılaşma konularında literature katkı sağlamak üzere çalışma yapmak isteyen araştırmacılara, çatışmanın yabancılaşmayı etkileyebileceği daha farklı değişkenleri incelemeleri önerilmektedir. Ayrıca araştırma sonuçlarının genellenebilirliğinin artırılması açısından evren ve örneklem yığınlarının çoğaltılması tavsiye edilmektedir. Araştırmacıların söz konusu çalışmaları nitel araştırma yöntemleri kullanarak geliştirmeleri de ayrıca önerilmektedir.

\section{KAYNAKÇA}

Atak, M. (2005). Örgütlerde Resmi Olmayan İletişimin Yeri ve Önemi. Havacıllk ve Uzay Teknolojileri Dergisi, 2, 59-67.

Aydoğan, E. (2015). Marx ve Öncülerinde Yabanc1laşma Kavramı. Atatürk Üniversitesi Edebiyat Fakültesi Dergisi, 54, 273-282.

Can, G. Ş. (2016). Küreselleşmeyle Gelişen Yabancılaşma Kavramı ve Sanat. The Journal of Academic Social Science Studies. 51, 229-236.

Çetinkaya M. C. (2019). Psikolojik Dayaniklilik Ve Örgütsel Yabancilaşma Arasindaki Ilişki: Birey-Örgüt Uyumu, Birey-Iş Uyumu, Işten Ayrilma Niyeti Ve Algilanan Örgütsel Desteğin Düzenleyicilik Rolü (Perakende Sektörü Örneği). Yayınlanmamış Doktora Tezi, Çukurova Üniversitesi, Adana.

Ceylan, A., ERGÜN, E., ALPKAN, L. (2000). Çatışmanın Sebepleri ve Yönetimi, Doğuş Üniversitesi Dergisi. $1(2), 39-51$

Demir, Ö. ve ACAR, M. (1997). Sosyal Bilimler Sözlüğ̈̈. Ankara: Vadi Yayınları.

Elma, C. (2003). Ilköğretim Okulu Öğretmenlerinin Isşe Yabancılaşması (Ankara İli Örneği), Yayınlanmamış Doktora Tezi, Ankara Üniversitesi, Ankara.

Eren, E. (2008). Yönetim ve Organizasyon (8. Baskı). İstanbul: Beta Basım Yayım Dağıtım.

Eryllmaz, A. ve Burgaz, B. (2011). Özel ve Resmi Lise Öğretmenlerinin Örgütsel Yabancılaşma Düzeyleri. Eğitim ve Bilim Dergisi. 36(161), 271-286.

Haqe, S. H. (2019). Yöneticilerin Örgütsel Çatışma Yönetiminde Modern Liderlik Tarzlarının Rolü: Süleyman Demirel Üniversitesi İle Bağdat Üniversitesi’nde Karşılaştırmalı Bir Araştırma, Yayınlanmamış Doktora Tezi, Süleyman Demirel Üniversitesi, Isparta.

Jandt, F. E., (2016). Conflict ve Communication. Califronia: Sage Publications.

Kaplanoğlu, E. (2014). Mesleki Stresin Temel Nedenleri ve Muhtemel Sonuçları: Manisa İlindeki SMMM'ler Üzerine Bir Araştırma, Muhasebe ve Finansman Dergisi, 64, 131-150.

Karcıoğlu, F., Kahya, C., Buzkan, K. (2012). Çatışma Yönetim Stratejisinin Tahmin Edicileri Olarak Örgütsel Kültür Tipleri. Atatürk Üniversitesi İktisadi ve İdari Bilimler Dergisi, 26(1), 77-91.

Karip, E. (2013). Çatışma Yönetimi (5. Baskı). Ankara: Pegem A Yayıncılık.

Koçel, T. (2013) İşletme Yöneticiliği (14. Baskı). İstanbul: Beta Basım.

Korkmaz, S. (1994). Örgütsel Çatışma Yönetimi ve Verimlilik. Verimlilik Dergisi, 1, 77-94.

Minibaş, J. (1993). Yabancılaşma Kavramının İncelenmesi ve Banka Sektörüne Yönelik Bir Araştırma, Yayımlanmamış Doktora Tezi, İstanbul Üniversitesi, İstanbul.

Ofluoğlu, G. ve Büyükyılmaz, O. (2008). Yabancılaşmanın Teorik Gelişimi ve Tarihsel Süreç İçinde Farklı Alanlarda Görünümleri. Kamu-İș İş Hukuku ve İktisat Dergisi. 10(1), 113-144.

Öngen, T. (2009). Marks (Sınıf) ve Weber (Statü) Çözümlemelerinde Bir Uğrak Olarak Meslek ve Hekimlik. Toplum ve Hekim Dergisi. 24(2), 83-90.

Özkalp, E. (2004). Davranış Bilimlerine Giriş. Eskişehir: T.C. Anadolu Üniversitesi Yayını No:1355

Öztürk, M. (2003). Fonksiyonları Açısından İşletme ve Yönetim. İstanbul: Papatya Yayıncılık.

Rahim, A. (2010). Functional and Dysfunctional Strategies for Managing Conflict, 23rd Annual International Association of Conflict Management Conference, 1-15.

Rahim, M. A. (2001). Managing Conflict in Organizations (Third Edition). Westport: Quorum Books.

Şahin, A., Emini, F. T., Ünsal, Ö. (2006). Çatışma Yönetimi Yöntemleri Ve Hastane Örgütlerinde Bir Uygulama. Selçuk Üniversitesi Sosyal Bilimler Enstitüsü Dergisi. 15, 553-568.

Sasikala, P., Kalaivani, K., Agalya, Y. (2014). A Study on Emerging Issues of Conflict Management in Management Practice of Organizational Climate. Journal of Business Management ve Social Sciences Research. 3(10), 53-57. 
Seeman, M. (1959). On The Meaning of Alienation. American Sociological Review, 24(6), 783-791.

Seeman, M. (1983). Alienation Motifs in Contemporary Theorizing: The Hidden Continuity of the Classic Themes. Social Psychology Quarterly, 46(3), 171-184.

Simmel, G. (1999). Çatışma Fikri ve Modern Kültürlerde Çatışma, İstanbul: İz Yayıncılık.

Şimşek, M. Ş., Çelik, A., (2014). Meslek Yüksek Okulları İçin Yönetim ve Organizasyon (5. Baskı). Konya: Eğitim Yayınevi.

Solmuş, T. (2001). Örgütlerde Kişilerarası-Gruplararası Çatışmalar ve Çatışma Yönetimi. Türk Psikoloji Bülteni, $20,42$.

Türkçe Sözlük (2010). Yabancılaşma. Ankara: Türk Dil Kurumu Yayınları.

Türkçe Sözlük, Çatışma, $\quad 01.03 .2017 \quad$ tarihinde http://tdk.gov.tr/index.php?option=com_btsvearama=kelimeveguid=TDK.GTS.588748bfc7dab6.7654141 $\underline{3}$ adresinden alınmıştır.

Üngüren, E., (2008). Örgütsel Çatışma Yönetimi Üzerine Konaklama İşletmelerinde Bir Araştırma. Uluslararası Sosyal Araştırmalar Dergisi, 1(5), 880-909.

Uysal, İ., (2004). Örgütsel Çatışma Yönetimi ve Türkiye Cumhuriyet Merkez Bankası'na Yönelik Bir Uygulama, Yayımlanmamış Uzmanlık Yeterlilik Tezi, Türkiye Cumhuriyet Merkez Bankası, Ankara.

Yamane T. (2001). Temel Örnekleme Yöntemleri (Çeviri: Esin A., Bakır M. A., Aydın C., Gürbüzsel E.). İstanbul: Literatür Yayınları.

Yatkın, A., (2008). Örgütsel Çatışmanın Ve Performans Değerlemenin İşgören Performansına Etkileri. Fırat Üniversitesi Doğu Anadolu Araştırma ve Uygulama Merkezi Dergisi, 6(2), 6-18.

Yılmaz, Ö. (2016). Örgütsel Çatışma Yönetiminde Örgütsel Vatandaşlık Davranışının Rolüne İlişkin Bir Araştırma. Yayınlanmamış Doktora Tezi, Dokuz Eylül Üniversitesi, İzmir.

Yöntembilim Terimleri Sözlüğü. (1981). Çatışma. Ankara: Türk Dil Kurumu Yayınları. 


\section{EXTENDED ABSTRACT}

Organization is a concept that emerges as a result of people coming together. Therefore, it is unthinkable that physical and psychological phenomena that affect people individually or collectively in organizations are not examined and not associated with this issue. There are a number of reasons that reduce people's sense of belonging to the organization they are a member of. Failure to investigate and resolve these reasons causes organizations to fail to achieve their goals and objectives or to reach them later and at a higher cost. In this context, whether the conflict existing in organizations has an effect on the alienation of employees, and if yes, to what extent it has been examined in this study.

The concept of conflict has appeared in various forms since the day human beings existed. Conflict, which has been used more in the sense of fighting in history, today refers to a broader meaning, including sociology and psychology. Conflict occours between two or more individuals or groups. It is the case that the goals, demands, expectations or motives are not compatible with each other (Öztürk, 2003: 262).

Organizational conflict is a disagreement or conflict arising from the distribution of scarce resources or distribution of activities among individuals or groups within the organization and the differences in status, purpose, value or perception between these individuals or groups (Solmuş, 2004: 37). In other words, organizational conflict is the events that arise from the problems of individuals and groups while working together for the same purpose and cause the normal activities to pause or interfere (Eren, 2008: 609).

Along with the growth and diversification of enterprises in the historical process, changes have been observed in the perception of organization and organizational conflict in different periods. In the traditional business management age, conflict is considered as an undesirable object that needs to be removed. Managers are responsible for eliminating the conflict that negatively affects the organization and disrupts its functioning (Şahin et al., 2006: 555). In the behavioral period, which is also called the neoclassical period, the view that organizational conflict is natural and inevitable is dominant and the view of benefiting from this phenomenon by accepting it instead of eliminating it has been accepted (Yatkın, 2008: 13). In the modern business management approach, conflict is considered as a positive phenomenon as it brings a number of innovations and different perspectives to organizations. In this approach, conflicts are inevitable and it is necessary to have a certain level of conflict in organizations seen as open systems (Koçel, 2013: 646).

A number of practical strategies have been developed for the management of organizational conflict. When the literature in question was examined, it was Afzalur Rahim from Western Kentucky University who developed generally accepted strategies and brought them to science. He has also developed an organizational conflict inventory called ROCI (Rahim Organizational Conflict Inventory). The strategies are as follows; collaborating, accommodating, competing, avoiding and compromising.

The concept of alienation is a frequently encountered concept in daily life. Alienation, which is the subject of many disciplines, also affects people's behavior. When evaluated individually, alienation is defined as "loss of interest in the society, cultural values and role distribution, seeing values and norms as meaningless, feeling powerless and lonely" (Demir ve Acar, 1997: 217).

In the historical process, what is understood from the concept of alienation has changed according to the conditions of that day and has developed based on a number of new facts. According to Hegel, alienation is a result of the distinction between human physical and spiritual beings (Ofluoğlu ve Büyükyllmaz, 2008: 115). Marx associated alienation with economics in a materialist framework (Aydoğan, 2015: 273). On the other hand, German Sociologist Simmel explained alienation as creating a distance between a person's consciousness and emotional state as a result of the loneliness, the obligation to compete and the need to stand alone in modern life (Can, 2016: 231). The subject of alienation in terms of business science is that an employee working in a workplace is distanced from his workplace, his employer or his colleagues due to a number of reasons and the bonds of belonging are reduced or completely broken.

When the definition of the sub-dimensions that make up alienation as a superior concept is examined, it is understood that the titles of powerlessness, meaninglessness, normlessness, isolation and self-alienation are generally accepted in literature (Seeman, 1959: 783-791). 
The aim of this study is to determine whether there is a relationship between organizational conflict and alienation and to what extent it is. For this purpose, people were selected from among employees working in the central organization of a ministry by simple random sampling method. Collection of data used in the study was achieved by the survey method.

The raw data obtained after the survey study were analyzed using the Statistical Package for the Social Sciences (SPSS 26) program. In this process, correlation and simple regression analysis and test method were applied.

There are questions about demographic information in the first part of the survey form. The inventory of conflict in the second part of the survey form was introduced by Rahim (1983) and developed again by him (ROCIII 2001). The organizational alienation inventory used in the third part of the survey was created by Minibaş (1993) and was used in the doctoral thesis after its reliability was tested again by her.

It is revealed that a population of 3675 people and at least 348 samples are needed for this research. Considering that the sample number used in the study is 404 , it is seen that the mentioned number is sufficient.

The result of testing the hypotheses; It has been determined that there is a positive significant relationship between organizational alienation.

According to the results of the simple regression analysis made for the effect of organizational conflict on organizational alienation, it is seen that the conflict scale has a positive and significant effect on alienation.

In addition, in the first stage of the hierarchical regression analysis, it is seen that conflict has a positive and significant effect on powerlessness. In the second stage of the analysis, it is seen that conflict, which is the independent variable, has a positive and significant effect on powerlessness and normlessness. In the third stage of the analysis, it was determined that conflict has a significant effect on powerlessness, normlessness and meaninglessness.

As a result of the $t$ test; It has been determined that the gender of the employees has no effect on the conflict and alienation levels. In addition, it was determined that the marital status of the employees did not have any effect on their conflict and alienation levels.

When the literature on the subject was examined, there was no study that directly examined the relationship between both variables. In this context, the relevant variables were evaluated separately. In the study conducted by Yilmaz (2016), a positive significant relationship was found between conflict management and organizational citizenship behavior. In addition, in another study by Haqe (2019), it was concluded that certain leadership roles affect organizational conflict. In the research carried out by Çetinkaya (2019) on the retail sector, it was concluded that there is a significant negative relationship between psychological resilience and organizational alienation.

It is recommended that managers who will work within the framework of conflict management in organizations know that they will also manage the alienation issue and carry out relevant activities within this scope. The results of the study should be considered by the managers in terms of contributing to saving financial resources, human resources and time.

Researchers who want to contribute to the literature on organizational conflict and organizational alienation are also recommended to examine different variables that conflict may affect alienation, increase the generalizability of the research results, increase the population and sample stacks, and develop them using qualitative research methods. 